\title{
REVISITING COFFEE SHOPS AS PUBLIC SPACE IN PURWOKERTO
}

\author{
Aidatul Chusna(' $\left.{ }^{*}\right)$, Arizal Mutahir ${ }^{(2)}$, Muhammad Taufiqurrohman ${ }^{(3)}$ \\ ${ }^{13}$ Faculty of Humanities, Jenderal Soedirman University, Central Java, Indonesia. \\ ${ }^{2}$ Faculty of Social and Political Sciences, Jenderal Soedirman University, Central Java, Indonesia.
}

\section{ARTICLE INFORMATION}

$\begin{array}{ll}\text { Submitted } & : 01^{\text {st }} \text { March } 2021 \\ \text { Review } & : 01^{\text {st }} \text { October } 2021 \\ \text { Accepted } & : 15^{\text {th }} \text { Nopember } 2021 \\ \text { Published } & : 18^{\text {th }} \text { December 2021 }\end{array}$

Available Online : December 2021.

KEYWORDS

Coffee shops; public sphere; youngsters; leisure time.

CORRESPONDENCE

*E-mail: aidatul.chusna@unsoed.ac.id

\begin{abstract}
A B S T R A C T
The increasing number of coffee shops identifies the dynamics of urban life in Purwokerto. However, how does the existence of these coffee shops influence the socio-cultural life of the society? The research aims to examine the socio-cultural functions of coffee shops in Purwokerto in accordance to the role of public sphere. The concept of public sphere by Jurgen Habermas is used the theoretical foundation of the analysis. Using descriptive qualitative method, the study analyses data taken from the observation and interview process. Due to the large number of coffee shops in Purwokerto, the researchers select six coffee shops with different characteristics. The research finds that coffee shops in Purwokerto tend to be a place to meet up after school or work and spend their leisure time, as the coffee shop offers a good atmosphere to be more focused and productive on their work. Thus, the function of public sphere is hardly found. Instead, coffee shop becomes a private place for individuals to engage with their own individuality and communities.
\end{abstract}

\section{A. INTRODUCTION}

C offee is not the main agricultural product in Banyumas Indonesia. The 2018 Banyumas Regency Data and Information report (Banyumas, 2018) mentions that the total coffee production in Banyumas ranges from 143 tons per year-which includes 133 tons of Robusta coffee and 10.12 tons of arabica coffee. This number is far behind the total production of coffee in several districts of Central Java, such as Kendal Regency with the production of 2,860 tons per year, Semarang Regency which reaches 3,447 tons in one -year production, or Temanggung Regency with its coffee production reaches 9.562 tons per year. (Direktorat Jenderal Perkebunan, 2017).

The data above indicates that coffee is not a daily drink for the people, especially of Purwokerto, the capital city of Banyumas Regency. However, in reality, the opposite phenomenon appears, proven by the increasing number of coffee shops built in Purwokerto. The location of the coffee shops is varied, starting from the downtown to the alleyways or located in the city to remote villages. Based on the preliminary observations, there are at least 70 coffee shops in Purwokerto. They are members of a coffee lover community called Juguran Kopi. There are still many others that do not belong to the community. The number reaches tens, even maybe hundreds.

Beni, one of the activists of the Juguran Kopi community, said that coffee shops in Purwokerto are open from 8:00 a.m. to 24:00 p.m. Some are even open 24 hours throughout the week (interview conducted on 21 November 2018). In a day there are at least 100 visitors. If it is assumed that each coffee shop is visited by 200 people per day, there are around 1,400 visitors in coffee shops that are members of the coffee lover community. This number doesn't include the non-member of the coffee lover community.

The number of the visitors shows that drinking coffee has become a daily habit. That reality is different from the situation of the last decade. Rio, 
an activist of the coffee lover community, stated that the existence of coffee shops in Purwokerto began to grow in 2009. The number was still limited, but it had been increasing rapidly since 2016 (the preliminary interview on November 21, 2018). Some offer coffee drink in a typical dish, which adds to the rampant coffee shops in Purwokerto. Coffee shops become interesting places to visit.

The existence of coffee shops in Indonesia does not only attract coffee lovers but also researchers. Research about the history and development of coffee shop business owned by Chinese families in Makassar (Riswan, 2013) is a case in point. Another research focuses on the role of coffee shops to convey their ideas, individual and collective concern towards the poor life and working condition of lower-class society of Gresik (Ditrastiko, 2009). Meanwhile, a study on coffee found in Belitung shows that coffee shops become a meeting point for people from different age, ethnicity, religion and profession (Erman, 2016). Different studies were conducted on the behaviour of coffee lovers in Semarang (Solikatun, Kartono, \& Demartoto, 2015) and the coffee culture in Indonesia and how coffee is served in shops (Gumulya \& Helmi, 2017). Another research on coffee shop business in the Belike Coffee Shop and Balad Coffee Works, Jatinangor, reveals that product, location, facilities, equipment, human resources and competition are varying potentials, while the increasing price of coffee raw materials, noise, the absence of parking spaces constrained the business (Rasmikayati, Afriyanti, \& Saefudin, 2020).

The existence and growth of coffee shops in Purwokerto becomes the main concern of this study, as the existing studies only focus on the coffee production and distribution (Bambang, 2016; Barokatuminalloh \& Widayaningsih, 2009; Noehdijati, Sutanto, Sumanto, \& Widyasunu, 2017). The study of coffee shops in socio-cultural context becomes significant, providing the growth of the coffee shops and the production of coffee as shown by the above data. This study aims to reveal the socio-cultural functions of coffee shops in Purwokerto.

In his seminal work entitled The Structural Transformation of the Public Sphere: An Inquiry into A Category of Bourgeois Society, Habermas describes the early development of public sphere in the eighteenth century by the bourgeois society. Public sphere refers to a space in which private individuals gather and have equal access or opportunity to present ideas or opinions related to public interest. Opposed to the state, or the institutions, the sphere as public in Habermas' concept, refers to the privates or non-governmental people who make opinion. A public sphere includes certain norms, namely: (1) public accessibility; (2) eliminination of privileges/equal participation; and (3) the outcome of general rules and rational legitimations (Habermas, 2006). This study aims to examine the extent to which the coffee shops in
Purwokerto function as a public sphere by using Habermas's conception.

\section{B. METHOD}

Whis research applies descriptive qualitative method, as it concerns with a socio-cultural phenomenon, which is the development of coffee shops in Purwokerto and its effects, socially and culturally, on the society. Cresswell mentions the descriptive qualitative research uses data from questionnaires, interviews, documentation data, visual as well as audio data (Novianti \& Fatonah, 2019: 220). The data of this research are the audio-visual texts. The visual data is photos of the coffee shops' interior designs. Meanwhile, the audio-formed data are acquired from the interview with the owner/manager and the customers of the coffee shops.

Given the large number of coffee shops in Purwokerto, this study took six coffee shops as the research objects that were considered representative in "a broader socio-cultural context outside the text" (Davis, 2008). Those are: Singgah Coffee and Books, Kedai Koe, Suluk, Society Coffee House, @kopi, and Kebon Kopi. The coffee shops are selected based on their peculiarities and uniqueness, as seen from the variety of spatial concepts, the presentation patterns, and the variety of customers. Facing business competition, the owners or the managers of the coffee shops strive to present distinctive taste of coffee and other dishes as well as uniqueness in other forms, such as location selection and interior design. The six coffee shops selected represents such strategy. However, this uniqueness certainly brings a broader influence, especially in relation to the use of coffee shops as public spaces. It becomes the main concern of this research.

Moreover, in-depth interviews were conducted to obtain information from the owner/ the manager about the background of coffee shop opening and management. More importantly, interviews with several customers of the coffee shops become other empirical data needed to discuss the socio- cultural function of coffee shops in Purwokerto. The data is then supplemented with the description of the coffee shops, including the architectural style and exterior as well as interior designs. Overall, this information becomes the main data to examine the socio-cultural function of coffee shops along with the growth of Purwokerto as an urban area.

\section{RESULTS AND DISCUSSION}

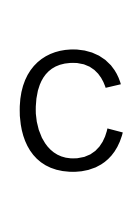
offee shop becomes one of the public spaces which marks the growth of urban life in Purwokerto. A space, according to Lefebvre, is produced in accordance to its function and how it impacts in everyday life. The space produced by each society will vary 
depending on their needs and priorities (Zieleniec, 2016). Thus, some questions related to the function of the coffee shops arises. Are they present to be public spheres for the people? To what extent these coffee shops become a site of public sphere? The discussion below focuses on investigating the existence and socio-cultural function of coffee shops in Purwokerto. Prior to the discussion, the six coffee shops are described, which include the background, the physical setting and the types of customers. These descriptions are based on the observation and interview with the owners and customers.

\section{Visiting the Coffee Shops}

The followings are the description of the six coffee shops, based on our observation and interview.

\section{a. Singgah Coffee and Books}

This coffee shop was open in 2016 in Purwokerto, as a business expansion of the coffee shop which was initially open in 2012 in Yogyakarta. The coffee shop is located near the biggest campus in the city, considering the main target of consumer is college students. Other targets which are expected to be the café customer is white collar workers and middle- class family. Based on the information of the owner, students and white-collar workers are the majority who often visit the coffee shop. Also, more surprisingly, this coffee shop has attracted high schoolers, proven by the increasing number of high school students visit the place.

In regard to the customers' type, Singgah is equipped with minimalist design interior with collection of books and low tone music/instrument to create a calm ambience. The owner Mahesa prefers the design as he usually visits coffee shops alone to read books or enjoy the ambience created by the coffee shop. When he finally succeeded in setting up his own coffee shop, he chose his favourite concept.

A college student named Azzah (23 years old), who is the customer of Singgah, says that he visits the coffee shop two or three times every week, and more often when he has an assignment to do. He argues that it provides a good place for students like him to hang out or finish his assignments. He even spends hours writing his thesis in this place. The calm ambience distinguishes Singgah with other coffee shops in Purwokerto.

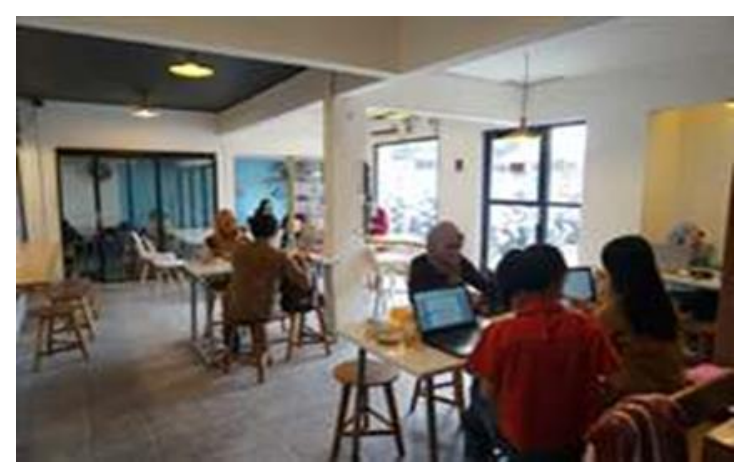

Figure 1.

The minimalist style interior design and the majority customers of Singgah Coffee and Books

Another customer, named Rio (27 years old), visits Singgah Coffee and Books for meeting with his friends as the price of the food and beverages of the coffee shops is more reasonable for college students who are from middle class family. Moreover, as Azzah, Rio likes visiting this coffee shop due to the vibes of the place. Singgah Coffe and Books has a good atmosphere for customers like him who need to focus on his college assignment and to meet up with his friends.

\section{b. Kedai Koe}

As previously stated, coffee shops are rapidly growing in Purwokerto and creating a higher competition in the coffee shop business. Kedai Koe is one of the oldest. Open in 2006, it was initiated by the cooperation between Telapak, an NGO from Bogor (West Java) and local NGO called Kompleet. Initially, Kedai Koe was opened as a place for similar communities to meet up and make coordination, as stated by Duwi, the manager of the coffee shop below:

"Actually, from the beginning is 'Kedai Telapak' (the firstly-used name of the coffee shop), before it was renamed several times. The pattern that we actually used was a place for community members to gather. Not doing business first and then accommodating the community. There's a community first and then there is a need for coffee. Then, the coffee shop was founded to accommodate this need. We are indeed (begun from) the community"

Thus, community members become the main target of Kedai Koe. In other words, profit is not the main concern of the founder; it is more used for the continuity of the coffee shop. Unfortunately, today the coffee shop has less customers due to the lack of good management. Duwi further argues that it should become the main agenda to invite more communities. 
"Our task is now holding the communities together and improving facilities that used to be able to serve the communities' needs such as film screening, by getting permission from the residents in its neighbourhood. As public screening is used to be complained about, some communities prefer to moving to other places"

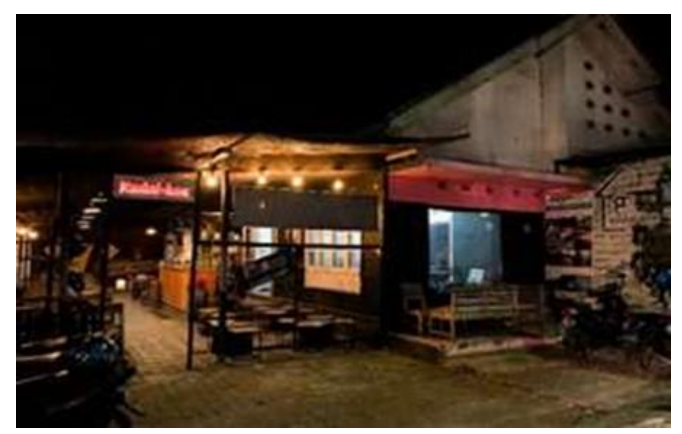

Figure 2.

The wooden dominated and minimalist interior design of Kedai Koe.

\section{c. Suluk}

Open firstly on May 12, 2017, Suluk becomes one of the most promising coffee shops in Purwokerto. The building uses Joglo- a Javanese traditional house, and wooden furniture. The traditional concept is also supported by the location of the coffee shop, which is beside rice fields. Bagir, the owner of the coffee shop, said that the Joglo belongs to his grandparents. As they no longer live in that house, he moved and transformed it into a coffee shop.

The unique characteristic that distinguishes Suluk from other coffee shops in Purwokerto is its main menu, which is the combination of various coffee drinks with Pecel, a Javanese traditional salad which contains mixed vegetables with peanut sauce dressing and is usually served with steamed rice or lontong or ketupat (rice cake). Bagir's decision in opening a coffee shop with traditional taste is welcomed by the customers, proven by more customers visit this place.

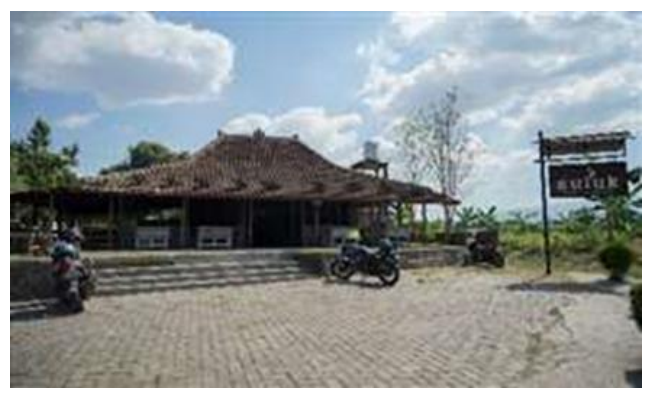

Figure 3. 'Joglo' house represents Suluk's simplicity and traditional concept
Similar to Singgah and Kedai Koe, Suluk coffee shop also has a wide range of customers. It is undeniable that the location of the coffee shops influences the type of the consumers. Unlike coffee shops in general, Suluk is located in suburban area with rice fields nearby. This is coupled with the concept of Joglo and traditional dishes, which completes the rural atmosphere presented. This atmosphere brings its own familiarity to its loyal customers, which apparently many know each other individually or between groups of visitors. This is very different from coffee shop visitors in general, who do not know each other.

Moreover, only a few miles from Jenderal Soedirman University, Suluk coffee shop is mostly visited by college students. Meeting and socializing become an urban lifestyle that can be found in any cities, including Purwokerto. The owner admits that students give major profit for the business. In holiday season, as he continues, the number of customers is falling significantly.

Another type of customers is entrepreneurs/businessmen. Yuli (30-year-old) and Leli (33-year-old), for example, often come to Suluk coffee shop to meet their friends. They even called the place as their "base camp" to describe their familiarity with the place and its owner. They chose Suluk instead of other coffee shops since, for them, the quality of the coffee served is better than those served in other coffee shops. Leli said that she had visited many coffee shops, but Suluk offers the best taste of the coffee.

"Initially I didn't like coffee and got indigestion after drinking coffee. First time trying coffee here (at Suluk coffee shop), I really liked it. Then I looked for other comparisons, but I didn't get the taste, the coffee here is the most suitable for me. Moreover, if other coffee shops offer an "instagramable" interior concept, but usually a place like that are not comfortable to hang out for long ... For example, the place is limited, you won't be able to stay longer as the seats will be used by other customers. If you want to hang out with friends, laughing in a crowded and closed place won't be comfortable. It's freer here"

Similarly, Yuli mentions that he likes visiting Suluk as the place is more open than other coffee shops. With a patio design, Suluk offers a place for the customers to speak more freely without bothering other customers. Yuli further states that he feels more comfortable to meet his business partners in Suluk as it provides a good place for business meeting with an informal and warm atmosphere which creates closeness to his partners. Moreover, Suluk coffee shop gives affordable price of the food and beverages, so that it's suitable for the middleclass segmentation, as such college students and business people. 


\section{d. Society Coffee House}

Society Coffee House was firstly open on February 2015, after a three-year preparation. Hendy, the owner of the coffee shop, mentions that he decides to open Society Coffee House as he needs a place to hang out after work.

"the history is dated back to the end of 2012, when I was back to Purwokerto. As someone who had just graduated from college, I just really loved hanging out and playing. But mostly hanging out. l'd helped parents in the office, it's like working for 5-8 hours every day. Now after that hour, there's no more work, right? So, jamming and hanging out were my most frequent activities after work"

Coffee shop was chosen as he had not found any eatery which put coffee as the main menu. Back in 2012, a place with 'coffee specialty', as he called it, was hardly found in Purwokerto. Thus; the concept was quite unique at that time.

With its industrial design, Society Coffee House meets the customers' need. Bet, who works in a cruise ship, mentions that he visits Society Coffee House almost every day during his off-duty period. For him, the place is comfortable to sit and relax, since it has wide space for individuals or groups of customers to do their own activities without disturbing others. Despite its location in the downtown, Society Coffee House is calm and relaxing; and the customers, as well as the music played are not noisy. The similar reason is also stated by Talita, a college student, who often visits Society Coffee House to do assignment, to hang out and chat with her friends. With a good ambience of the coffee shop, she can spend five hours in Society Coffee House.

"first, there is Wi-Fi that I need to finish my work and to be online with my cell phone. In addition, the place is just comfortable as it is big so it's cool to talk with friends, as other customers could not overhear us. It's different from other small cafes, with their box shaped spaces so when the customers at one table are chattering, we could hear their voice and sometimes we feel disturbed. So, we feel comfortable here, if we chat, people won't hear to us"

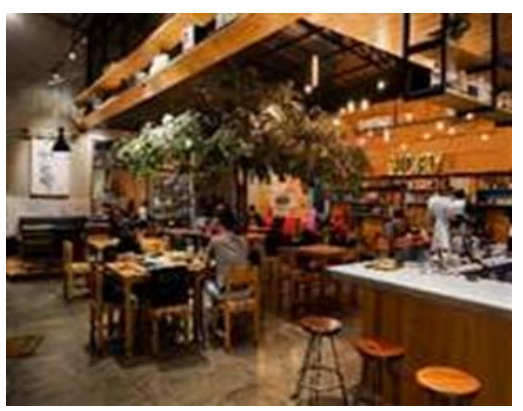

Figure 4.

The interior design of Society Coffee House, which provides separated rooms for smoker and nonsmoker customers.

Like other coffee shops in general, Society Coffee House becomes a place to relax and leisure, to meet up and chatter, or to do school or business works. However, the majority customer of this coffee shop come from upper class family, considering the higher price of the food and beverages compared to other coffee shops in Purwokerto.

\section{e. @Kopi}

@Kopi was firstly open in October 2014. Beny, the owner of the coffee house, opened the place for two reasons. The first is personal reason; he loves coffee. The second is to educate people about Indonesia's coffee. Beny argues that Indonesia has the best coffee in the world, so people should know about it.

"firstly, I love coffee; secondly, Indonesian coffee is the best in the world. Then, at that time, in Purwokerto there was no education about Indonesian coffee. That's my reason. So, the background is that I want to introduce Indonesian coffee which is arguably the best"

As he moved to Purwokerto, 'fresh coffee' was hardly found in the area. Beni has known and liked fresh coffee since 1993, when he visited various places in Indonesia and brought local coffee beans as the souvenirs.

Apart from Beny's fondness of coffee, @kopi was also opened for the need of social interaction. People need to meet up, to socialize, and talk about various matters; and @kopi provides the place. Initially, the customers who come to the coffee shop are the owner's friends and community. Nowadays, more customers come to the place individually or in group. Each has different reason; some people come to enjoy the coffee, while others need a place for discussion. Yet, there is no events organized or held in this coffee shop. In other words, @kopi tends to be a place for individuals or groups of people to deal with their own personal matters. 


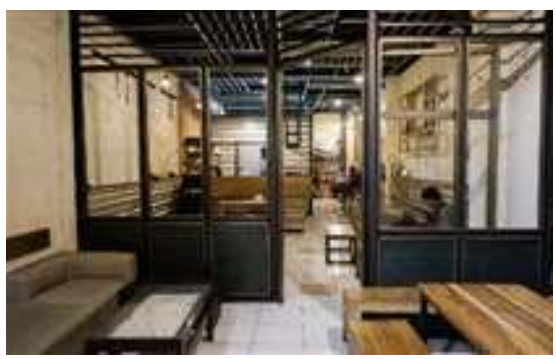

Figure 5.

The minimalist interior design of @Kopi

\section{f. Kebon Kopi}

On its first opening in 2006, Kebon Kopi was located at a bus garage which was no longer used. Initially, the coffee shop was named Kebon Kopi dan Pondok Seni (coffee shop and art house), as it also provided a space for art appreciation and music show. However, it was closed in 2011. In 2016, the owner reopened it in a downtown area for a year, then moved to a place near campus area. The last location has changed the typical customers of Kebon Kopi. More college students are coming and become the regular customer. Jihan (22 years old) is a student from the campus nearby. She often visits the coffee house- five times a week to enjoy her leisure time alone. However, out of her frequency, she has made new friends who are also the regular customers.

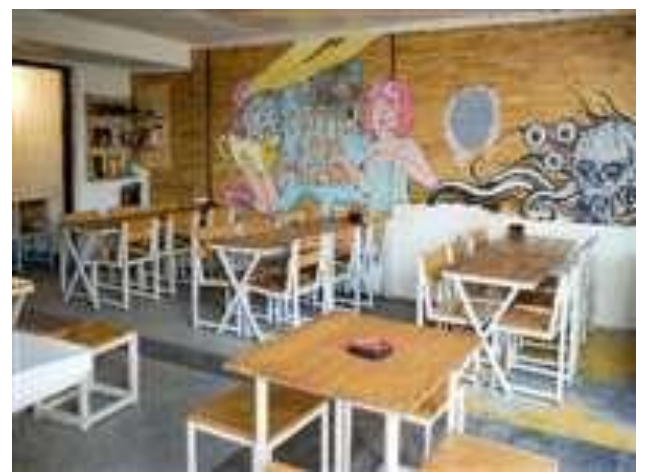

Figure 7.

The interior design of Kebon Kopi

Kebon Kopi also functions as a meeting point for its customers. Satrio (36 years old) is another customer who comes to the coffee shop five times in a week. He has known the place for long time. He argues that Kebon Kopi has become a 'creative hub' that provides a room and opportunity for entrepreneurs like him to join the business. With the support from Sampoerna- one of the biggest cigarette companies in Indonesia, Kedai Kopi often holds events which invites entrepreneurs to display and promote their products to the visitors.
Kebon Kopi also becomes an alternative place for business meeting. Satrio comes to the place to do 'cash on delivery' of his products and meet potential consumers. Moreover, the coffee shop is also a place to enjoy his leisure time after work. He has made many friends who are also the regular customers of the coffee shop. These customers are unintentionally grouped with no specific goals. They just meet and talk trivial matters. Thus, the common need for leisure time put them in a similar place and situation.

\section{The Socio-Cultural Functions of the Coffee Shops}

The socio-cultural functions of coffee shops represent the interface between place and human experience. Relph (Seamon \& Sowers, 2008) believes that in examining a place thoroughly, "people's identity of and with place" is pivotal. He further argues that the identity of place refers to "the sameness and unity which allows [the place] to be differentiated from others", and it can be viewed from three factors: "(1) the place's physical setting, (2) its activities, situations, and events; and (3) the individual and group meaning created through people's experiences and intentions in regards to that place". Through aspects of physical settings, activities, and meaning, this study examines the socio-cultural functions of coffee shops in Purwokerto. By revealing these functions, this study will prove whether the coffee shops can be regarded as public spaces for the people of Purwokerto.

Based on the in-depth interview with the owners and the customers, as well as the lay-out and interior design, coffee shops becomes an alternative space in relation to the consumers' productivity. Many customers, especially office workers and college students, choose to complete their assignment at this place. The need is then responded by the coffee shops by providing a comfortable space with a good internet connection. Furthermore, coffee shop is often used as business meetings and cooperation. The ambience provides more intimate and intense meetings compared to those held in the office.

The coffee shops become a place for leisure activities such as enjoying coffees, reading books, online gaming, spending time on social media, and posting selfies on Instagram and Facebook. These activities are accommodated by public places as coffee shops for the people who could afford it; in this case, the middle and upper class. In short, the growing number of coffee shops in Purwokerto proves that along with "the development of contemporary industrialized societies", as Del Pino Atarcho puts it, "created the structural conditions that led to an explosion of leisure and activities that support it" (Brasileiro, 2013). As a developing city, Purwokerto attracts more people to live and be part of the community. As an industrialized urban area; however, Purwokerto is only apt for those who could afford the living standard, which are the middle to 
upper class society. Thus, despite its heterogeneous inhabitants, Purwokerto tends to provide more modern lifestyles than its surrounding areas.

Leisure is part of urban lifestyles. Moreover, the industrialized societies have also changed the types of leisure activities and the spaces as well. Zukin notes that the growing attention on lifestyle brings about "new, highly visible consumption spaces" and it makes places like malls, restaurants or coffee shops develop "strategies that 'aestheticise', or focus on the visual consumption of, public space" (Zukin, 1998). This condition is shown by the interior design of coffee shops in Purwokerto. Thus, the coffee shop has turned into a more aesthetic public space to accommodate the visual consumption desired by its consumers.

The physical setting of the place (which includes the so-called instagrammable designs, the menu and the prices, and the music played), the events, and the individuals who most regularly visit the coffee shops indicate that coffee shops are only limited for those who come from certain socioeconomic groups- mostly the middle and upper class society, and social status, which are the white-collar workers, college students and high schoolers. These consumers make use of the coffee shops' features to construct and engage with their social identity. In this era, more social interaction is mediated through social media, as it provides a space to its users to post their photos to state their social status and to connect and communicate with their community (Roem \& Sarmiati, 2019).

Coffee shop thus becomes a commodity. Consumer society, as Baudrillard suggests, is highlighted by commodity and consumption in which individuals gain prestige, identity, and social upright. By this system, the more prestigious one's commodities, the higher one's standing in the sphere of sign value (Kellner, 2003). In this realm, coffee shop is a sign value for its consumers, through the style, prestige, and power provided by the place. By visiting coffee shops, the customers do not only buy the coffee drink but also 'purchase the place'. By enjoying times at the coffe shops, and posting their selfies to social medias, customers are building their self-images to be shown to public.

In short, in regard to Habermas' ideal concept of public sphere, coffee shops in Purwokerto do not meet the criteria. The coffee shops are spaces for public, but not the public that Habermas referred to. The public, as Habermas meant, is not simply a crowd. It is defined as the opposite of institutions; the public is meant as individuals who gather and equally participate in public matters (Habermas, 2006). The three criteria that Habermas mentioned are hardly found in the coffee shops in Purwokerto. Instead of being a public sphere for people to gather and have equal opportunity to exchange ideas, opinions, and solution for the sake of public interest, coffee shops in Purwokerto tend to be a private sphere, in which individuals come, or gather with their own community, for their own matters. Coffee shops become a closed realm that only those who can afford to purchase and consume the product can be part of the space. Coffee shop functions as a symbolic space for settling ones' identity and social status.

\section{CONCLUSIONS}

$\mathrm{T}$ he existence of coffee shops denotes the growing of Purwokerto as urban area. People, mostly youngsters, visit coffee shop to meet up and chat after school/work, and as an alternative place to finish assignments. It is also a place to do business relation and cooperation. These functions mean that the coffee shops tend to be a site for doing/having their own personal matters. The absence of discussion forums in the coffee shops indicates the function of coffee houses as 'public sphere' no longer exist. It has been transformed into a place for leisure and relaxation and part of the lifestyle of the urban people. The typical customers who come to coffee shop also negates the ideal of public sphere which is open for any people regardless their social status and classes. Instead, it becomes a site for constructing social identity for the consumer. Moreover, becoming the regular customers of the coffee shops make them part of the community. Therefore, becoming a public space where everyone regardless of social class can gather and meet for a common goal is not part of the socio-cultural function of coffee shops in Purwokerto. Coffee shops nowadays tend to function as a commodity to construct identity.

\section{E. ACKNOWLEDGMENT}

W e'd like to thank the Institute of Research and Community Services of Jenderal Soedirman University (LPPM Unsoed) for the financial and institutional support in the completion of this research. We also thank the owners and managers of the coffee shops who have been very helpful in providing information needed for the research.

\section{REFERENCES}

Bambang, B. (2016). Pemetaan Potensi Desa di Kabupaten Banyumas. EcceS Economics, Social, and Development Studies, 3(1): 123-155. 
Banyumas, K. (2018). Data dan informasi kabupaten Banyumas 2018. Available online from: https://banyumaskab.bps.go.id/publication/2018/08/16/a70faf0fe6d4c623995cfb5e/kabupatenbanyumas-dalam-angka-2018.html [Accessed December 10, 2019]

Barokatuminalloh, \& Widayaningsih, N. (2009). Saluran Pemasaran Kopi yang Efisien di Kecamatan Karanglewas Kabupaten Banyumas. Eko-Regional, 4(2): 97-104.

Brasileiro, M. D. S. (2013). Leisure and Social Transformations; From Modern Times to Postmodernity. Lusophone Journal of Cultural Studies, 1(2): 109-125.

Davis, A. (2008). Investigating Cultural Producers. In M. Pickering (Ed.), Research Method for Cultural Studies (pp. 53-67). Edinburgh: Edinburgh University Press.

Direktorat Jenderal Perkebunan. (2017). Statistik Perkebunan Indonesia (2015-2017): K o p i. Available on line from https://drive.google.com/file/d/1SEf5k9dopUfgVCpdz0D9qlmSHPc4l-Qd/view [Accessed December 2, 2019]

Ditrastiko, R. T. (2009). Fenomena Warung Kopi Uyel (Studi Pemaknaan Warung Kopi Uyel bagi Penggemar Kopi Di Gresik). Available onlinefrom: http://repository.unair.ac.id/17023/ [Accessed December 28, 2019]

Erman, E. (2016). Dinamika Komunitas Warung Kopi Dan Politik Resistensi Di Pulau Belitung. Masyarakat Indonesia, Jurnal Masyarakat Indonesia, 40(1): 89-107. Doi: https://doi.org/10.14203/jmi.v40i1.108

Gumulya, D., \& Helmi, I. S. (2017). Kajian Budaya Minum Kopi di Indonesia. Dimensi, 13(2): 153-172. Available online from https://trijurnal.lemlit.trisakti.ac.id/index.php/dimensi/article/viewFile/1785/1545 [Accessed October $4,2021]$

Habermas, J. (2006). The Public Sphere: An Encyclopedia Article. In M. G. Durham \& and D. M. Kellner (Eds.), Media and Cultural Studies (2nd ed., pp. 73-78). Malden: Blackwell Publishing Ltd.

Kellner, D. (2003). Jean Baudrillard. In G. Ritzer (Ed.), The Blackwell Companion to Major Contemporary Social Theorists (2nd ed., pp. 310-332). Malden: Blackwell Publishing Ltd.

Noehdijati, D. E., Sutanto, A., Sumanto, B., \& Widyasunu, P. (2017). Identifikasi Kopi Desa Sunyalangu Kecamatan Karanglewas Kabupaten Banyumas. Jurnal LPPM Unsoed, 7(1): 356-362.

Noviyanti, D. \& Fatonah, S. (2019). Budaya Literasi Media Digital pada Ibu-lbu Rumah Tangga. Jurnal Antropologi, 21(2), 218-226. https://doi.org/10.25077/jantro.v22.n2.p218226.2019

Rasmikayati, E., Afriyanti, S., \& Saefudin, B.R., (2020). Keragaan, Potensi dan Kendala pada Usaha Kedai Kopi Di Jatinangor (Kasus pada Belike Coffee Shop dan Balad Coffee Works). Agritekh (Jurnal Agribisnis dan Teknologi Pangan), 1(1), 26-45.

Riswan, A. (2013). Perkembangan Warung Kopi Phoenam 1946-2006. Available online from: http://repository.unhas.ac.id/handle/123456789/6032 [Accessed December 28, 2019].

Roem, E.R, \& Sarmiati, (2019). Perubahan Sosial Budaya akibat Media Instagram bagi Kalangan Mahasiswi di Kota Padang. Jurnal Antropologi. 21(2), 202-2010. https://doi.org/10.25077/jantro.v22.n2.p202210.2019

Seamon, D., \& Sowers, J. (2008). Place and Placelessness (1976): Edward Relph. In Key Texts in Human Geography (pp. 43-51). Retrieved from https://www.academia.edu/10820364/PLACE_ AND_PLACELESSNESS_1976_Edward_Relph_2008_

Solikatun, Kartono, D. T., \& Demartoto, A. (2015). Perilaku Konsumsi Kopi Sebagai Budaya Masyarakat Konsumsi: Studi Fenomenologi Pada Peminum Kopi Di Kedai Kopi Kota Semarang. Jurnal Analisa Sosiologi, 4(1): 60-74.

Stevenson, D. (2003). Cities And Urban Cultures (Issues in Cultural and Media Studies). Maidenhead: Open University Press.

Zieleniec, Andrzej. (2016). The right to write the city: Lefebvre and graffiti. Environnement Urbain. 10. Available online from: https://journals.openedition.org/eue/1421?lang=en

Zukin, S. (1998). Urban Studies Urban Lifestyles: Diversity and Standardisation in Spaces of Consumption. Urban Studies, 35(5): 825-839. https://doi.org/10.1080/0042098984574 